Quality : Jurnal Kesehatan

Volume 15, Nomor 2 Tahun 2021

pISSN : 1978-4325, eISSN : 2655-2434, DOI: 10.36082/qjk.v15i2.209

\title{
DETERMINAN PRAKTIK PEMBERIAN ASI EKSKLUSIF
}

\author{
Ns. Indah Permatasari, M.Kep ${ }^{1}$, Ns. Ritanti, M.Kep., Sp.Kep.An ${ }^{2}$ \\ ${ }^{1}$ Departemen Keperawatan Anak FIKES UPN Veteran Jakarta \\ ${ }^{2}$ Departemen Keperawatan Komunitas FIKES UPN Veteran Jakarta
}

\begin{tabular}{ll}
\hline Info Artikel & Abstrak \\
\hline Genesis Naskah: & Cakupan pemberian ASI eksklusif dalam kurun waktu tahun 2013-2015 di Indonesia hanya \\
Submitted: $8-3-2021$ & sekitar 54,1\% bayi di Indonesia yang mendapatkan ASI eksklusif. Hasil penelitian Latifah, \\
Revised: 17 19-06-2021 & Purwanti dan Sukamto(2020) menunjukkan kurangnya asupan gizi pada anak terkhusus \\
Accepted:31-05-2021 & pemberian ASI Eksklusif berdampak pada angka kejadian stunting pada anak. Jika dilihat dari \\
& akibatnya stunting dapat berdampak pada tingkat kecerdasan, kerentanan terhadap penyakit, \\
Kata Kunci: & menurunkan produktifitas dan kemudian menghambat pertumbuhan ekonomi, meningkatkan \\
ASI Eksklusif, Program, & umum penelitian ini untuk menganalisis faktor prediktor praktik pemberian ASI eksklusif dan \\
Puskesmas & pengaruh menyusui eksklusif terhadap pertumbuhan bayi 6 bulan pertama kelahiran di Kecamatan \\
& Baros. Penelitian ini adalah penelitian deskriptif analitik dengan menggunakan metode kuantitatif. \\
& Sampel dalam penelitian ini sebanyak 220 bayi lahir hidup yang berusia 7-12 bulan yang \\
& memenuhi kriteria inklusi dan kriteria eksklusi. Hasil penelitian menunjukkan bahwa pekerjaan \\
& ibu dan kunjungan ANC berhubungan dengan keberhasilan praktik pemberian ASI eksklusif (p- \\
& value=0,001 dan p-value = 0,000). Hasil analisis multivariat menunjukkan ibu dengan \\
& pengalaman kunjungan ANC $\geq 4$ kali memiliki kemungkinan 6 kali lebih tinggi untuk \\
& memberikan ASI eksklusif kepada bayi mereka dibandingkan ibu dengan kunjungan ANC $<$ dari \\
& 4 kali.
\end{tabular}

\begin{tabular}{|c|c|}
\hline \multicolumn{2}{|c|}{ DETERMINANTS OF EXCLUSIVE BREASTFEEDING PRACTICE } \\
\hline Keywords: & Abstract \\
\hline $\begin{array}{l}\text { Exclusive breastfeeding, } \\
\text { programs, health centers }\end{array}$ & $\begin{array}{l}\text { The coverage of exclusive breastfeeding in the period } 2013-2015 \text { in Indonesia was only about } \\
54.1 \% \text { of babies in Indonesia who received exclusive breastfeeding. Banten area is one of the } \\
\text { areas that contribute to stunting cases in Indonesia (14\%). When viewed from the consequences, } \\
\text { stunting can have an impact on the level of intelligence, susceptibility to disease, reduce } \\
\text { productivity and then inhibit economic growth, increase poverty and inequality in Indonesian } \\
\text { society (Riskesdas, 2018). The general objective of this study was to analyze the predictor factors } \\
\text { for exclusive breastfeeding practice and the effect of exclusive breastfeeding on the growth of } \\
\text { babies in the first } 6 \text { months of birth in Baros District. This research is a descriptive analytic study } \\
\text { using quantitative methods. The sample in this study were } 220 \text { live born babies aged } 7-12 \text { months } \\
\text { who met the inclusion and exclusion criteria. The results showed that maternal occupation and } \\
\text { ANC visits were associated with the success of exclusive breastfeeding practices (p-value = } 0.001 \\
\text { and p-value }=0.000 \text { ). The results of the multivariate analysis showed that mothers with ANC } \\
\text { visits } \geq 4 \text { times were } 6 \text { times more likely to provide exclusive breastfeeding to their babies than } \\
\text { mothers with ANC visits }<4 \text { times. }\end{array}$ \\
\hline
\end{tabular}

Korespondensi Penulis:

Indah Permatasari

Jl. RS. Fatmawati, Pondok Labu, Jakarta Selatan, DKI Jakarta, 12450

Email: indahpermatasari@upnvj.ac.id

(C) Poltekkes Kemenkes Jakarta I

ISSN 2655-2434

Jl. Wijaya Kusuma No. 47-48 Cilandak Jakarta Selatan, Indonesia

email: jurnalquality@poltekkesjakarta1.ac.id

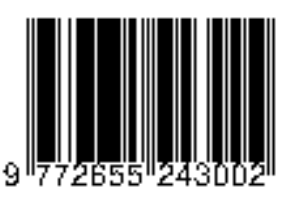




\section{Pendahuluan}

Pemberian ASI pada bayi sedini mungkin sangat dianjurkan dikarenakan isapan pertama bayi memberikan beberapa keuntungan bagi ibu antara lain produksi ASI menjadi terstimulasi, membantu mengurangi kehilangan darah pada masa nifas, memupuk rasa kasih sayang antara ibu dan bayi, memperpanjang jarak kelahiran sehingga memberikan kesempatan bagi tubuh ibu untuk pulih pasca melahirkan (Badan Pusat Statistik, 2018). Akan tetapi, berbagai keuntungan yang diperoleh ibu khususnya belum mampu mencapai target program secara nasional yaitu sebanyak $80 \%$ bayi diberikan ASI sejak kelahiran sampai usia 6 bulan ASI eksklusif (Kementerian Kesehatan Republik Indonesia, 2019).

Cakupan pemberian ASI eksklusif di Indonesia masih jauh dari harapan. Secara nasioanal pada tahun 2017 angka pemberian ASI Eksklusif masih $61,33 \%$. Angka ini masih jauh dari target yang ditetapkan oleh pemerintah yaitu $80 \%$ (Kementerian Kesehatan Republik Indonesia, 2019). Menyusui merupakan investasi terbaik untuk kelangsungan hidup serta meningkatkan kesehatan, perkembangan sosial, ekonomi individu dan bangsa. Walaupun angka inisiasi menyusui secara global relatif tinggi, tapi hanya $40 \%$ dari semua Bayi dibawah umur 6 bulan yang mendapatkan ASI Eksklusif dan $45 \%$ yang mendapatkan ASI sampai usia 24 bulan. (Fadlliyyah, 2019)

Berbagai faktor berpengaruh terhadap praktik pemberian ASI eksklusif antara lain sosial demografi ibu (Kurniawan, 2013). Beberapa penelitian memberikan hasil bahwa umur ibu, pendidikan ibu, pekerjaan ibu, pendidikan suami, pekerjaan suami, penghasilan keluarga, jenis persalinan, tempat persalinan, paritas, frekuensi pemeriksaan kehamilan, inisiasi menyusu dini (IMD), konseling laktasi, niat untuk menyusui eksklusif dengan praktik pemberian ASI eksklusif berhubungan dengan praktik pemberian ASI eksklusi (Purnama Sari, Handayani dan Febry, 2019).

Data Dinas Kesehatan Provinsi Banten Tahun 2017 menunjukkan angka cakupan pemberian ASI sebesar $61,6 \%$, dan sebaran pemberian ASI Eksklusif dengan data terendah

(C) Poltekkes Kemenkes Jakarta I

Jl. Wijaya Kusuma No. 47-48 Cilandak Jakarta Selatan, Indonesia email: jurnalquality@poltekkesjakarta1.ac.id berada di Kecamatan Baros Banten. Hasil telaah literatur juga menunjukkan belum ada data yang menunjukkan faktor penyebab rendahnya angka cakupan pemberian ASI Eksklusif di daerah tersebut. (Dinas Kesehatan Provinsi Banten, 2017).

ASI eksklusif adalah makanan paling baik bagi bayi yang selain mengandung zat-zat gizi yang diperlukan untuk masa pertumbuhan bayi, namun juga merupakan makanan bagi bayi yang paling aman, tidak memerlukan biaya tambahan dalam proses pengolahannya, serta ASI mengandung berbagai zat kekebalan/ anti infeksi yang tidak dimiliki oleh susu formula sehingga dapat melindungi bayi dari berbagai penyakit infeksi (diare dan ISPA) yang menjadi penyebab utama dari kematian pada bayi dan anak (Yusrina dan Devy, 2017).

Dari hasil telaah jurnal menunjukkan belum ada penelitian yang menghubungkan faktor pemberian ASI ekskusif terhadap pertumbuhan anak di wilayah kerja kecamatan tersebut, melainkan hanya sebatas gambaran pemberian ASI Eksklusif di daerah tersebut. oleh karena itu pada penelitian kali ini, peneliti tertarik untuk mengetahui hubungan faktor sosial demografi terhadap praktik pemberian ASI Eksklusif dengan pengaruh praktik pemberian ASI Eksklusif dan Non-Eksklusif terhadap pertumbuhan bayi usia 0-6 bulan di Kecamatan Baros.

\section{Metode}

Penelitian ini adalah penelitian deskriptif dan analitik dengan menggunakan metode penelitian Kuantitatif. Desain studi yang digunakan adalah untuk melihat hubungan antara faktor sosial demografi dengan praktik pemberian ASI eksklusif dan pengaruh antara praktik menyusui selama 6 bulan terhadap pertumbuhan bayi (0-6 bulan). Sampel dalam penelitian ini adalah bayi yang dilahirkan hidup yang telah berusia 7-12 bulan yang memenuhi kriteria inklusi dan kriteria eksklusi. Adapun kriteria inklusi adalah:

a) Anak terakhir dan atau anak pertama

b) Berat lahir $\geq 2500$ gram

c) Ibu bersedia menjadi responden

Sedangkan kriteria eksklusi adalah:

a) Kelahiran kembar

b) Kelahiran premature 
c) Bayi yang memiliki catatan berat badan yang tidak lengkap selama 0-6 bulan

d) Bayi dengan penyakit serius (penyakit jantung, penyakit DM)

Perhitungan sampel dalam penelitian ini menggunakan Uji Hipotesis Proporsi Independen Dua Kelompok dua sisi (Lemeshow) dengan total besar sampel berjumlah 220 bayi dengan perhitungan sampel digambarkan pada tabel 1 berikut.

Tabel 1. Besar Sampel

\begin{tabular}{|c|c|c|c|c|c|c|}
\hline \multicolumn{2}{|c|}{ No Variabel } & Penelitian (thn) & P1 & $\mathbf{P 2}$ & \multirow{2}{*}{$\begin{array}{l}\text { (n) } \\
28\end{array}$} & \multirow{2}{*}{\begin{tabular}{|l|}
$(2 n)$ \\
56 \\
\end{tabular}} \\
\hline 1. & Kunjungan & Seid et al & $52,1 \%$ & $16,7 \%$ & & \\
\hline & ANC & (2013) & & & & \\
\hline \multirow[t]{2}{*}{2.} & Tempat & Seid et al & $53,2 \%$ & $22,1 \%$ & 37 & 74 \\
\hline & bersalin & (2013) & & & & \\
\hline \multirow[t]{2}{*}{3.} & Pekerjaan ib & Hamade et al & $13,8 \%$ & $35,8 \%$ & 60 & 120 \\
\hline & & (2013) & & & & \\
\hline \multirow[t]{2}{*}{4.} & Jenis & Seid et al & $52,5 \%$ & $32,9 \%$ & 99 & 198 \\
\hline & persalinan & (2013) & & & & \\
\hline
\end{tabular}

Pengambilan sampel dengan teknik acak berstrata yang dilakukan secara proporsional pada empat posyandu diwilayah kerja Puskesmas Baros, yaitu : Posyandu Arjuna, Posyandu Tunas, Posyandu Hanoman, dan Posyandu Srikandi.

Pengumpulan data primer dilakukan dengan dengan menggunakan kuesioner dengan jawaban sudah tersedia serta sebelumnya telah dilakukan uji validitas dan reliabilitas pada 30 responden dengan hasil uji validitas valid dengan nilai $\mathrm{r}$ hitung $>\mathrm{r}$ tabel dan hasil uji reliabilitas reliabel dengan nilai cronbach's alpha $>$ dari nilai dasar $(0,840>0,60)$. Data sekunder didapatkan dari instansi terkait anatar lain Dinas Kesehatan Kabupaten Serang Banten, dan data Puskesmas Kecamatan Baros, serta data posyandu dari kader puskesmas. Data yang dikumpulkan adalah data hasil penimbangan berat badan yang dilakukan di posyandu setiap bulan.

Metode analisa data pada penelitian ini melalui tiga tahapan yaitu: analisa univariat, analisa bivariat, dan analisa multivariate. analisa univariat merupakan tahapan awal yang berguna untuk menjelaskan/ menggambarkan karakteristik dari setiap faktor (independen dan dependen) . Analisis bivariat berguna untuk mengetahui hubungan antara faktor. Pada tahap ini pengujian hipotesis

(C) Poltekkes Kemenkes Jakarta I

J1. Wijaya Kusuma No. 47-48 Cilandak Jakarta Selatan, Indonesia email: jurnalquality@poltekkesjakarta1.ac.id dilakukan dengan uji Chi-square. Pengambilan keputusan statistik menggunakan Confidence Interval (CI) yaitu 95\% dan level of significance $(\alpha)$ sebesar $5 \%$. Analisis multivariat merupakan analisis yang digunakan untuk menghubungkan beberapa variabel bebas dengan variabel terikat secara komprehensif (Hardani Hardani, 2020) Variabel dependen pada penelitian ini adalah data kategorik, maka uji

\section{Hasil}

\section{A. Analisa Univariat}

Hasil data karakteristik pada responden ibu dengan anak usia dibawah 2 tahun dapat dilihat pada tabel berikut:

Tabel 2. Distribusi karakteristik responden

\begin{tabular}{|c|c|c|c|}
\hline No. & Variabel & Frekuensi & $\begin{array}{c}\text { Persentase } \\
(\%)\end{array}$ \\
\hline \multirow[t]{4}{*}{1} & Umur Ibu & & \\
\hline & $\begin{array}{l}<20 \text { tahun dan } \\
\text { atau }>35 \text { tahun }\end{array}$ & 75 & $34.1 \%$ \\
\hline & 20-35 tahun & 145 & $65.9 \%$ \\
\hline & Total & 220 & $100.0 \%$ \\
\hline \multirow[t]{4}{*}{2} & $\begin{array}{l}\text { Pendidikan } \\
\text { terakhir ibu }\end{array}$ & & \\
\hline & Rendah & 117 & $53.2 \%$ \\
\hline & Tinggi & 103 & $46.8 \%$ \\
\hline & Total & 220 & $100.0 \%$ \\
\hline \multirow[t]{4}{*}{3} & $\begin{array}{c}\text { Pendidikan } \\
\text { terakhir } \\
\text { suami } \\
\end{array}$ & & \\
\hline & Rendah & 116 & $52.7 \%$ \\
\hline & Tinggi & 104 & $47.3 \%$ \\
\hline & Total & 220 & $100.0 \%$ \\
\hline \multirow[t]{4}{*}{4} & Pekerjaan Ibu & & \\
\hline & Tidak bekerja & 155 & $70.5 \%$ \\
\hline & Bekerja & 65 & $29.5 \%$ \\
\hline & Total & 220 & $100.0 \%$ \\
\hline \multirow[t]{4}{*}{5} & $\begin{array}{c}\text { Pekerjaan } \\
\text { Suami }\end{array}$ & & \\
\hline & Tidak bekerja & 6 & $2.7 \%$ \\
\hline & Bekerja & 214 & $97.3 \%$ \\
\hline & Total & 220 & $100.0 \%$ \\
\hline \multirow[t]{4}{*}{6} & $\begin{array}{c}\text { Tingkat } \\
\text { kesejahteraan }\end{array}$ & & \\
\hline & Rendah & 181 & $82.3 \%$ \\
\hline & Tinggi & 39 & $17.7 \%$ \\
\hline & Total & 220 & $100.0 \%$ \\
\hline \multirow[t]{2}{*}{7} & Paritas & & \\
\hline & $<2$ anak & 65 & $29.5 \%$ \\
\hline
\end{tabular}

ISSN 2655-2434

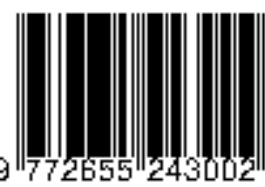




\begin{tabular}{|c|c|c|c|}
\hline & $>=2$ anak & 155 & $70.5 \%$ \\
\hline & Total & 220 & $100.0 \%$ \\
\hline \multirow[t]{4}{*}{8} & $\begin{array}{l}\text { Tempat } \\
\text { bersalin }\end{array}$ & & \\
\hline & Non faskes & 21 & $9.5 \%$ \\
\hline & Faskes & 199 & $90.5 \%$ \\
\hline & Total & 220 & $100.0 \%$ \\
\hline \multirow[t]{4}{*}{9} & $\begin{array}{l}\text { Penolong } \\
\text { persalinan }\end{array}$ & & \\
\hline & Non nakes & 13 & $5.9 \%$ \\
\hline & Nakes & 207 & $94.1 \%$ \\
\hline & Total & 220 & $100.0 \%$ \\
\hline \multirow[t]{4}{*}{10} & $\begin{array}{c}\text { Jenis } \\
\text { persalinan }\end{array}$ & & \\
\hline & Cesar & 30 & $13.6 \%$ \\
\hline & Normal & 190 & $86.4 \%$ \\
\hline & Total & 220 & $100.0 \%$ \\
\hline \multirow[t]{4}{*}{11} & $\begin{array}{c}\text { Kunjungan } \\
\text { ANC }\end{array}$ & & \\
\hline & < 4 kali & 97 & $44.1 \%$ \\
\hline & $>=4$ kali & 123 & $55.9 \%$ \\
\hline & Total & 220 & $100.0 \%$ \\
\hline
\end{tabular}

Sumber: Data Peneliti (2020)

Tabel 3. Prevalensi Pemberian ASI Eksklusif

\begin{tabular}{|c|c|c|c|}
\hline Variabel & Kategori & $\begin{array}{r}\text { Jumlah } \\
\text { (n) }\end{array}$ & $\begin{array}{c}\text { Presentase } \\
(\%)\end{array}$ \\
\hline \multirow{3}{*}{$\begin{array}{c}\text { Perberian } \\
\text { ASI } \\
\text { Ekskl } \\
\text { usif }\end{array}$} & $\mathrm{Ya}$ & 37 & $16.8 \%$ \\
\hline & Tidak & 183 & $83,2 \%$ \\
\hline & Total & 220 & $100 \%$ \\
\hline
\end{tabular}

Sumber: Data Peneliti (2020)

Pemberian ASI eksklusif di wilayah kerja Puskesmas Baros mengalami penurunan selama 6 bulan ditunjukkan dalam gambar 1 berikut.

Gambar 1. Pola Pemberian ASI Eksklusif dan Tidak Eksklusif pada Bayi Usia 6 Bulan

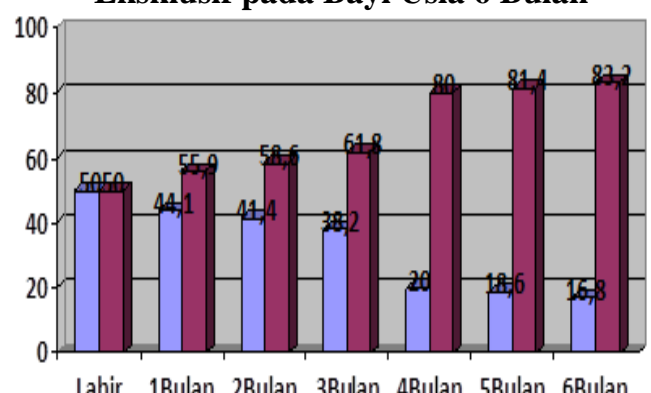

$\square$ ASI Eksklusif $\square$ ASI Tidak Eksklusif

Sumber: Data Peneliti (2020)

(C) Poltekkes Kemenkes Jakarta I

J1. Wijaya Kusuma No. 47-48 Cilandak Jakarta Selatan, Indonesia email: jurnalquality@poltekkesjakarta1.ac.id

\section{B. Analisa Bivariat dan Multivariat}

Analisis bivariabel dilakukan dengan menggunakan uji Chi-square. Pengambilan keputusan statistik menggunakan Confidence Interval (CI) yaitu 95\% dan level of significance $(\alpha)$ sebesar $5 \%$ serta melihat perbedaan rata-rata antar 2 kelompok dengan menggunakan Analisis Stratifikasi (Regresi Logistik).

Tabel 4. Determinan Pemberian ASI Eksklusif

\begin{tabular}{|c|c|c|c|c|c|c|}
\hline & & \multicolumn{4}{|c|}{ Pemberian ASI Eksklusif } & \\
\hline & & \multicolumn{2}{|c|}{$\begin{array}{c}\text { ASI Tidak } \\
\text { Eksklus } \\
\text { if } \\
\end{array}$} & \multicolumn{2}{|c|}{$\begin{array}{c}\text { ASI } \\
\text { Ekskl } \\
\text { usif }\end{array}$} & \\
\hline & & $\mathrm{n}$ & $\%$ & $\mathrm{n}$ & $\%$ & $p$-value \\
\hline \multirow[t]{2}{*}{$\begin{array}{l}\text { Umur ibu } \\
\text { melahirkan }\end{array}$} & $\begin{aligned} & <20 \\
\text { thn, } & \\
> & 35 \text { thn }\end{aligned}$ & 65 & $\begin{array}{c}86,7 \\
\%\end{array}$ & 10 & $\begin{array}{c}13,3 \\
\%\end{array}$ & $\mathbf{0 , 3 2 0}$ \\
\hline & $\begin{array}{c}20-35 \\
\text { thn }\end{array}$ & $\begin{array}{c}11 \\
8\end{array}$ & $\begin{array}{c}81,4 \\
\%\end{array}$ & 27 & $\begin{array}{c}18,6 \\
\%\end{array}$ & \\
\hline \multirow[t]{2}{*}{$\begin{array}{c}\text { Pendidikan } \\
\text { Ibu }\end{array}$} & Tinggi & 83 & $\begin{array}{c}80,6 \\
\%\end{array}$ & 20 & $\begin{array}{c}19,4 \\
\%\end{array}$ & $\mathbf{0 , 3 3 3}$ \\
\hline & Rendah & 100 & $\begin{array}{c}85,5 \\
\%\end{array}$ & 17 & $\begin{array}{c}14,5 \\
\%\end{array}$ & \\
\hline \multirow[t]{2}{*}{$\begin{array}{c}\text { Pendidikan } \\
\text { Suami } \\
\end{array}$} & Tinggi & 87 & $\begin{array}{c}83,7 \\
\%\end{array}$ & 17 & $\begin{array}{c}16,3 \\
\%\end{array}$ & $\mathbf{0 , 8 5 9}$ \\
\hline & Rendah & 96 & $\begin{array}{c}82,8 \\
\%\end{array}$ & 20 & $\begin{array}{c}17,2 \\
\%\end{array}$ & \\
\hline \multirow[t]{2}{*}{$\begin{array}{c}\text { Pekerjaan } \\
\text { Ibu } \\
\end{array}$} & $\begin{array}{c}\text { Tidak } \\
\text { bekerja }\end{array}$ & 137 & $\begin{array}{c}88,4 \\
\%\end{array}$ & 18 & $\begin{array}{c}11,6 \\
\%\end{array}$ & $\mathbf{0 , 0 0 1 *}$ \\
\hline & Bekerja & 46 & $\begin{array}{c}70,8 \\
\% \\
\end{array}$ & 19 & $\begin{array}{c}29,2 \\
\%\end{array}$ & \\
\hline \multirow[t]{2}{*}{$\begin{array}{c}\text { Pekerjaan } \\
\text { Suami } \\
\end{array}$} & $\begin{array}{c}\text { Tidak } \\
\text { bekerja }\end{array}$ & 6 & $100 \%$ & 0 & $0 \%$ & 0,264 \\
\hline & Bekerja & 17 & $\begin{array}{c}82,7 \\
\%\end{array}$ & 37 & $\begin{array}{c}17,3 \\
\%\end{array}$ & \\
\hline \multirow{2}{*}{$\begin{array}{c}\text { Tingkat } \\
\text { kesejahtera } \\
\text { an keluarga }\end{array}$} & <UMK & 154 & $\begin{array}{c}85,1 \\
\%\end{array}$ & 27 & 14,9 & 0,104 \\
\hline & $\geq \mathrm{UMK}$ & 29 & $\begin{array}{c}74,4 \\
\%\end{array}$ & 10 & $\begin{array}{c}25,6 \\
\%\end{array}$ & \\
\hline \multirow[t]{2}{*}{ Paritas } & $\begin{array}{c}<2 \\
\text { anak } \\
\end{array}$ & 54 & $\begin{array}{c}83,1 \\
\%\end{array}$ & 11 & $\begin{array}{c}16,9 \\
\%\end{array}$ & $\mathbf{0 , 9 7 9}$ \\
\hline & $\begin{array}{c}\geq 2 \\
\text { anak }\end{array}$ & 129 & $\begin{array}{c}83,2 \\
\%\end{array}$ & 26 & $\begin{array}{c}16,8 \\
\%\end{array}$ & \\
\hline \multirow[t]{2}{*}{$\begin{array}{c}\text { Tempat } \\
\text { bersalin }\end{array}$} & Faskes & 63 & $\begin{array}{r}81,9 \\
\% \\
\end{array}$ & 36 & $\begin{array}{r}18,1 \\
\%\end{array}$ & 0,120 \\
\hline & $\begin{array}{l}\text { Non- } \\
\text { faskes }\end{array}$ & 20 & $\begin{array}{r}95,2 \\
\% \\
\end{array}$ & 1 & 4,8 & \\
\hline \multirow[t]{2}{*}{$\begin{array}{l}\text { Penolong } \\
\text { persalinan }\end{array}$} & $\begin{array}{c}\text { Non } \\
\text { Nakes }\end{array}$ & 13 & $100 \%$ & 0 & $0 \%$ & 0,095 \\
\hline & Nakes & 70 & 82,1 & 37 & 17,9 & \\
\hline
\end{tabular}




\begin{tabular}{|c|c|c|r|r|r|r|}
\hline & & & $\%$ & & \multicolumn{2}{|c|}{} \\
\hline $\begin{array}{c}\text { Jenis } \\
\text { persalinan }\end{array}$ & Sesar & 23 & $\begin{array}{c}76,7 \\
\%\end{array}$ & 7 & 23,3 & $\mathbf{0 , 3 0 5}$ \\
\hline & Normal & 60 & $\begin{array}{c}84,2 \\
\%\end{array}$ & 30 & 15,8 & \\
\hline $\begin{array}{c}\text { Kunjungan } \\
\text { ANC }\end{array}$ & $<4$ kali & 22 & $\begin{array}{c}94,8 \\
\%\end{array}$ & 5 & 5,2 & $\mathbf{0 , 0 0 0}$ \\
\hline & $\geq 4$ kali & 91 & $74 \%$ & 32 & 26 & \\
\hline
\end{tabular}

Sumber: Data Peneliti (2020)

Tabel 4. Pemodelan Determinan Pemberian ASI Eksklusif di Wilayah Kerja Puskesmas Baros Tahun 2020

\begin{tabular}{|c|c|c|c|c|c|}
\hline & & & & $\begin{array}{r}95 \% \\
\text { EX }\end{array}$ & $\begin{array}{l}\text { I.for } \\
\text { (B) }\end{array}$ \\
\hline & & Sig. & $\operatorname{Exp}(B)$ & Lower & Upper \\
\hline Model 1 & Pekerjaan_ibu(1) & .005 & 3.038 & 1.395 & 6.615 \\
\hline & Pekerjaan_suami(1) & .999 & $\begin{array}{r}3047216 \\
86126\end{array}$ & .000 & \\
\hline & Tingkat_kesejahteraan( & .172 & 1.876 & .760 & 4.629 \\
\hline & Penolong_persalinan(1) & .999 & $\begin{array}{r}2613912 \\
05629\end{array}$ & .000 & \\
\hline & Kunjungan_ANC(1) & .001 & 5.893 & 2.154 & 16.120 \\
\hline & Constant & 998 & .000 & & \\
\hline Model 2 & Pekerjaan_ibu(1) & .006 & 2.915 & 1.351 & 6.289 \\
\hline & Pekerjaan_suami(1) & .999 & $\begin{array}{r}3076470 \\
77.636\end{array}$ & .000 & \\
\hline & Penolong_persalinan(1) & .998 & 2974588 & .000 & \\
\hline & Kunjungan_ANC(1) & .000 & 6.044 & 2.217 & 16.473 \\
\hline & Constant & .998 & .000 & & \\
\hline Model 3 & Pekerjaan_ibu(1) & .004 & 3.056 & 1.420 & 6.575 \\
\hline & Penolong_persalinan(1) & .998 & $\begin{array}{r}2888111 \\
93.206\end{array}$ & .000 & \\
\hline & Kunjungan_ANC(1) & .000 & 6.022 & 2.211 & 16.405 \\
\hline & Constant & .998 & .000 & & \\
\hline
\end{tabular}

Sumber: Data Peneliti (2020)

\section{Pembahasan}

Puskesmas Kecamatan Baros yang merupakan unit pelaksana teknis Dinas Kesehatan Kabupaten Serang berperan aktif dalam melaksanakan upaya-upaya peningkatan pelayanan kesehatan yang makin bermutu, makin merata dan makin terjangkau masyarakat luas, khususnya masyarakat di wilayah Puskesmas Baros. Visi Puskesmas Baros yaitu menurunkan angka kematian ibu (AKI) dan angka kematian Bayi (AKB) di wilayah kerja UPT Puskesmas Baros.

Hasil analisis univariat karakteristik responden pada tabel 1 menggambarkan responden ibu berusia 20-35 tahun sebanyak 145 orang (65,9\%), Pendidikan terakhir ibu sebanyak 117

(C) Poltekkes Kemenkes Jakarta I

J1. Wijaya Kusuma No. 47-48 Cilandak Jakarta Selatan, Indonesia email: jurnalquality@poltekkesjakarta1.ac.id orang $(53,2 \%)$ dan suami 116 orang $(52.7 \%)$ rendah/ tamat SD, Sebagian besar ibu tidak bekerja $70.5 \%$ (155 orang), sedangkan pekerjaan suami sebagian besar buruh $97.3 \%$ (214 orang), tingkat kesejahteraan responden sebagian besar rendah $82.3 \%$ (181 orang), paritas anak lebih dari 2 sebanyak $70.5 \%$ (155 orang), sebagin besar ibu melahirkan di fasilitas kesehatan $90.5 \%$ (199 orang), penolong persalinan sebagina besar nakes $94.1 \%$ (207 orang), jenis persalinan sebagian besar normal $86.4 \%$ (190 orang), dan lebih dari separuh ibu melakukan kunjungan ANC lebih dari 4x sebanyak $55.9 \%$ (123 orang).

Berat badan merupakan salah satu indikator yang dapat digunakan untuk memantau pertumbuhan (growth) pada bayi, khususnya dalam 6 bulan pertama kelahiran. Rata-rata berat bayi pada 6 bulan pertama kelahiran berkisar sebesar 7,3 kg. Pada triwulan I perkiraan penambahan berat badan sebesar 0,700-0,750 kg/bulan dan triwulan II sebesar 0,5-0,6 kg/bulan (Nilakesuma, Jurnalis dan Rusjdi, 2015). Nutrisi terpenting selama 6 bulan pertama kelahiran adalah ASI eksklusif yang mengandung berbagai zat gizi sempurna yang dibutuhkan bayi selama proses pertumbuhan dan perkembangannya antara lain karbohidrat, protein, lemak, vitamin, mineral. Pemberian ASI eksklusif di wilayah kerja Puskesmas Baros mengalami penurunan selama 6 bulan (Gambar 1). Gambar 1 menunjukkan bahwa proporsi bayi yang mendapatkan ASI eksklusif semakin menurun dalam kurun waktu 6 bulan pertama kelahiran, sedangkan proporsi bayi yang mendapatkan ASI tidak eksklusif semakin meningkat dalam kurun waktu yang sama. Berbagai alasan disampaikan oleh ibu terkait dengan ketidakberhasilan dalam memberikan ASI eksklusif kepada bayi mereka antara lain adanya persepsi yang keliru dari ibu yaitu ibu merasa ASI tidak cukup memenuhi kebutuhan nutrisi bayi, sehingga ibu memberikan makanan/ minuman selain ASI seperti air putih, madu, air kopi dan susu formula agar bayi menjadi kenyang. Selain itu, alasan tidak memberikan ASI eksklusif yang diungkapkan oleh ibu adalah bayi enggan menyusu dan ibu harus kembali bekerja (diza fathamira hamzah, 2018)

ISSN 2655-2434

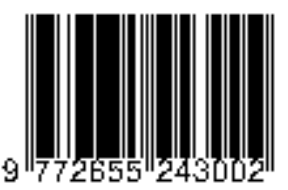


Hasil analisis bivariat pada tabel 3 menunjukkan bahwa pekerjaan ibu berhubungan dengan praktik pemberian ASI eksklusif $(\mathrm{OR}=3,144 ; 95 \%$ CI 1,521-6,498; p-value $=0,001)$. Selain pekerjaan ibu, riwayat kunjungan ANC juga berhubungan dengan keberhasilan praktik pemberian ASI eksklusif $(\mathrm{OR}=6,470$; $95 \% \mathrm{CI}$ 2,414-17,345) ; p-value $=0,000)$. Sementara, variabel lain yaitu umur ibu melahirkan, pendidikan ibu, pendidikan suami, pekerjaan suami, tingkat kesejahteraan keluarga, paritas, tempat bersalin, penolong persalinan, dan jenis persalinan tidak berhubungan dengan praktik pemberian ASI eksklusif. Hasil penelitian ini sejalan dengan penelitian Indah dkk (2019) bahwa ibu bekerja memiliki rata-rata pertambahan berat badan bayi yang lebih tinggi dibandingkan ibu-ibu yang lain. Pekerjaan ibu tidak menghalangi ibu untuk tetap terus memberikan ASI eksklusif kepada bayi (Anggraeni, Nurdiati dan Padmawati, 2016). Hal yang terpenting bagi ibu bekerja adalah adanya dukungan/ motivasi dari lingkungan keluarga antara lain suami, ibu/ ibu mertua, teman/ sahabat, pengasuh bayi dan tenaga kesehatan (Okawary dan Purwati, 2015).

Hasil analisis multivariat pada tabel 4 diperoleh hasil bahwa pekerjaan ibu dan kunjungan ANC merupakan variabel dominan terhadap pemberian ASI eksklusif pada bayi 0-6 bulan di wilayah kerja puskesmas Baros Tahun 2020. Ibu yang tidak bekerja memiliki kemungkinan 3 kali lebih tinggi untuk mem(Novita, 2015)berikan ASI eksklusif kepada bayi mereka dibandingkan ibu yang bekerja hal ini sejalan dengan hasil penelitian tentang Keberhasilan ibu bekerja dalam memberikan ASI eksklusif dipengaruhi oleh banyak faktor (Raj dan Fara, 2020) diantaranya penggalian informasi meliputi intensi ibu dalam memberikan ASI eksklusif, sikap positif

terhadap ASI eksklusif, norma yang dipersepsikan dari lingkungan sosial, efi kasi diri yang baik, budaya menyusui, keterampilan manajemen laktasi, dan hambatan lingkungan yang dialami oleh ibu (Iswari, 2018). Intensi untuk menyusui eksklusif telah dimiliki oleh ibu sejak hamil. Ibu yang bekerja di sektor formal memiliki perbedaan dalam melakukan manajemen laktasi dibandingkan dengan ibu yang bekerja di sektor informal (diza fathamira hamzah, 2018). Ibu mengalami beberapa

(C) Poltekkes Kemenkes Jakarta I

Jl. Wijaya Kusuma No. 47-48 Cilandak Jakarta Selatan, Indonesia email: jurnalquality@ poltekkesjakarta1.ac.id hambatan dan keterbatasan, namun ibu tetap berjuang untuk memberikan ASI Eksklusif(Anggraeni, Nurdiati dan Padmawati, 2016). Selain itu ibu dengan pengalaman kunjungan $\mathrm{ANC} \geq 4$ kali memiliki kemungkinan 6 kali lebih tinggi untuk memberikan ASI eksklusif kepada bayi mereka dibandingkan ibu dengan kunjungan ANC < dari 4 kali.

\section{Kesimpulan dan Saran}

Pemberian ASI eksklusif sangat penting sebagai upaya menunjang pertumbuhan dan perkembangan bayi selama 6 bulan pertama kelahiran. Selain itu, tingkat morbiditas bayi yang diberikan ASI eksklusif lebih rendah dibandingkan bayi yang tidak diberikan ASI eksklusif dan pekerjaan ibu serta riwayat ante natal care merupakan variabel yang paling dominan terhadap keberhasilan praktik pemberian ASI eksklusif di wilayah kerja Puskesmas Baros Tahun 2020.

Peningkatan pemahaman ibu mengenai pemberian ASI eksklusif yang dimulai dari sebelum hamil, pada saat hamil dan sebelum melahirkan melalui kegiatan konseling secara teratus, agar tertanam keinginan dan motivasi yang kuat untuk memberikan ASI saja (eksklusif) pada bayi sampai usia 6 bulan (Novita, 2015)

Peran aktif petugas kesehatan dalam melakukan monitoring bagi ibu yang memberikan ASI (petugas pro aktif dalam memberikan dukungan kepada para ibu) (Sabati dan Nuryanto, 2015)

Pemberian dukungan/ motivasi dari keluarga terdekat ibu seperti suami, ibu/ ibu mertua seperti memberikan apresiasi kepada ibu pada saat selesai menyusui, memberikan rasa nyaman pada ibu pada saat menyusui dsb.

\section{Daftar Pustaka}

Anggraeni, I. A., Nurdiati, D. S. dan Padmawati, R. S. (2016) "Keberhasilan ibu bekerja memberikan ASI eksklusif," Jurnal Gizi dan Dietetik Indonesia (Indonesian Journal of Nutrition and Dietetics), 3(2), hal. 69. doi: 10.21927/ijnd.2015.3(2).69-76.

Badan Pusat Statistik (tanpa tanggal). Tersedia pada:

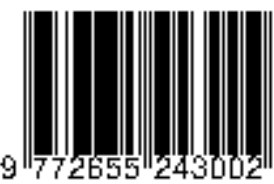


https://www.bps.go.id/publication/2018/07/03/5a96 3c1ea9b0fed6497d0845/statistik-indonesia2018.html (Diakses: 28 Februari 2021).

diza fathamira hamzah (2018) "pengaruh pemberian ASI Eksklusif terhadap berat badan bayi usia 4-6 bulan diwilayah kerja puskesmas langsa kota," 3(2), hal. 8-15.

Fadlliyyah, U. R. (2019) "Determinan Faktor Yang Berpengaruh Pada Pemberian Asi Eksklusif Di Indonesia," Ikesma, 15(1), hal. 51. doi: 10.19184/ikesma.v15i1.14415.

Hardani Hardani (2020) Buku Metode Penelitian Kualitatif \& Kuantitatif, CV. Pustaka Ilmu Grou. Tersedia pada:

https://www.researchgate.net/publication/34002154 8_Buku_Metode_Penelitian_Kualitatif_Kuantitatif (Diakses: 28 Februari 2021).

Iswari, I. (2018) "GAMBARAN PENGETAHUAN SUAMI DARI IBU MENYUSUI (0-6 Bulan) TENTANG ASI EKSKLUSIF DI WILAYAH KERJA PUSKESMAS DERMAYU KABUPATEN SELUMATAHUN 2017," Journal Of Midwifery, 6(1), hal. 10-16. doi:

10.37676/jm.v6i1.505.

Kementerian Kesehatan Republik Indonesia (tanpa tanggal). Tersedia pada: https://www.kemkes.go.id/ (Diakses: 6 Maret 2020).

Kurniawan, B. (2013) "Determinan Keberhasilan Pemberian Air Susu Ibu Eksklusif," Jurnal Kedokteran Brawijaya. Brawijaya University, 27(4), hal. 236-240. doi:

10.21776/ub.jkb.2013.027.04.11.

Latifah, A. M., Purwanti, L. E. dan Sukamto, F. I. (2020) "Hubungan Pemberian Asi Eksklusif Dengan Kejadian Stunting Pada Balita 1-5 Tahun," Health Sciences Journal, 4(1), hal. 142. doi: 10.24269/hsj.v4i1.409.

Nilakesuma, A., Jurnalis, Y. D. dan Rusjdi, S. R. (2015) "Hubungan Status Gizi Bayi dengan Pemberian ASI Ekslusif, Tingkat Pendidikan Ibu dan Status Ekonomi Keluarga di Wilayah Kerja Puskesmas Padang Pasir," Jurnal Kesehatan Andalas. Perpustakaan Universitas Andalas, 4(1).

(C) Poltekkes Kemenkes Jakarta I

Jl. Wijaya Kusuma No. 47-48 Cilandak Jakarta Selatan, Indonesia email: jurnalquality@poltekkesjakarta1.ac.id doi: 10.25077/jka.v4i1.184.

Novita (2015) "Faktor Yang Mempengaruhi Pemberian ASI," 7(STIKes Aliyah Semarang), hal. 1720-1730.

Okawary, O. dan Purwati, Y. (tanpa tanggal)

HUBUNGAN STATUS PEKERJAAN IBU DENGAN PEMBERIAN ASI EKSKLUSIF DI WILAYAH KERJA PUSKESMAS SEYEGAN SLEMAN YOGYAKARTA 1. Tersedia pada: www.health.detik.com, (Diakses: 28 Februari 2021).

Pemerintah Kota Serang (2016) "Profil Kota Serang," Review Dokumen RPIJM 2016 Bidang PU/Cipta Karya Kota Serang 2015-2019, hal. 50 halaman.

Purnama Sari, I., Handayani, D. dan Febry, F. (2019) "Prevalence and Predictors of Exclusive Breastfeeding Practices In Seberang Ulu I, Palembang: A Cross-Sectional Study," Jurnal Ilmu Kesehatan Masyarakat. Faculty of Public Health of Sriwijaya University, 10(3), hal. 163-171. doi: 10.26553/jikm.2019.10.3.163-171.

Raj, J. F. dan Fara, Y. D. (2020) "WELLNESS AND HEALTHY MAGAZINE Faktor yang mempengaruhi pemberian ASI eksklusif," 2(2), hal. 283. Tersedia pada: https://wellness.journalpress.id/wellness.

Sabati, M. R. dan Nuryanto, N. (2015) "Peran Petugas Kesehatan Terhadap Keberhasilan Pemberian Asi Eksklusif," Journal of Nutrition College, 4(4), hal. 526-533. doi: 10.14710/jnc.v4i4.10158.

Yusrina, A. dan Devy, S. R. (2017) "Faktor Yang Mempengaruhi Niat Ibu Memberikan Asi Eksklusif Di Kelurahan Magersari, Sidoarjo," Jurnal PROMKES, 4(1), hal. 11. doi: 10.20473/jpk.v4.i1.2016.11-21. 